\title{
Soil fertility changes in vineyards of a semiarid region in Brazil
}

\author{
Welka Preston ${ }^{1}$, Clístenes Williams Araújo do Nascimento², Yuri Jacques Agra Bezerra da \\ Silva $^{3 *}$, Davi José Silva ${ }^{4}$, Hailson Alves Ferreira ${ }^{5}$
}

${ }^{I}$ Federal Rural University of Semiarid /UFERSA, Department of Agronomy, Francisco Mota street, 572 - Costa e Silva, Mossoró 59.625-900, Rio Grande do Norte, Brazil. ${ }^{2}$ Federal Rural University of Pernambuco, Department of Agronomy, Dom Manuel de Medeiros street, s/n - Dois Irmãos 52171900, Recife, Pernambuco, Brazil. ${ }^{3}$ Federal University of Piaui, Department of Soil Science, Planalto Horizonte 64900-000, Bom Jesus, Piaui, Brazil. ${ }^{4}$ Brazilian Agricultural Research Corporation/Embrapa - Semiarid, Petrolina, PE, Brazil. '5Federal University of Rio Grande do Norte/UFRN, Agricultural Sciences Campus, Rio Grande do Norte, Brazil. Corresponding author: yuriufrpe@yahoo.com.br

\begin{abstract}
Cultivation can substantially change soil quality through improvement or degradation of the physical and chemical characteristics. Vineyard soils are sensitive to soil changes due to the intensive chemical input. This study assesses the soil fertility changes in vineyard soils of the São Francisco valley in Northeastern Brazil during different cultivation time spans $(5,6,8,10,12,15$, and 16 years). An area with natural vegetation (Caatinga) was used as a reference area. We analyzed $\mathrm{pH}$, exchangeable contents of $\mathrm{Ca}, \mathrm{Mg}, \mathrm{Na}, \mathrm{K}$, and $\mathrm{Al}$, potential acidity $(\mathrm{H}+\mathrm{Al})$, available $\mathrm{P}$, total organic matter, sum of bases, $\mathrm{CEC}, \mathrm{Al}$ saturation, and base saturation at depths of 0-20 and 20-40 cm. Univariate and multivariate analyses were used for data evaluation. The results showed that soil fertility changes were closely related to cultivation time spans. Contents of organic matter, $\mathrm{Ca}, \mathrm{Mg}$, and $\mathrm{K}$ were increased in most of the vineyard soils. The management of $\mathrm{P}$ fertilization deserves attention as the very high concentrations in soil are prone to leach and can contribute to triggering eutrophication. Discriminant and factor analyses proved to be useful tools for distinguishing the effects of management in the cultivated areas and helping to achieve sustainable land use in such fragile agro-ecosystems.
\end{abstract}

Keywords: Arid environments, soil organic matter, chemical fertilizers, grape cultivation

\section{Introduction}

The São Francisco Valley is the largest producer and exporter of fine table grapes in Brazil. To meet the high production demand, intensive chemical input through fertilizers and pesticides is needed (Freitas et al., 2011; Brasil, 2014). Several factors need to be managed effectively to achieve high yields, especially 
irrigation, fertilization, and chemical control. Therefore, studies on the effects of agricultural practices on soil quality and sustainability are of paramount importance, especially for crops with intensive chemical input (Serrano et al., 2017).

The São Francisco Valley is located in a semiarid region of Northeastern Brazil and has one of the largest public irrigation projects in the country. Soils in this valley are generally sandy and present very low levels of organic matter (OM) and phosphorus. These characteristics make the soils very fragile towards chemical alteration. Vineyards are often planted after removing the natural Caatinga vegetation to introduce crops. The removal of the natural cover, the addition of fertilizers, and intensive agricultural operations have triggered changes in the chemical properties of soils in this region (Silva et al., 2014). These changes can affect both crop yield and the quality of the soil environmental (Fernández-Calviño et al., 2010; Wightwick et al., 2013; Duplay et al., 2014; Silva et al., 2014; Brunori et al., 2016; Preston et al., 2016), resulting in either improvement of the soil properties or accelerated soil degradation (Jiao et al., 2012).

Irrigated soils commonly undergo chemical, physical, and biological changes in a relatively short time and with magnitude that varies as a function of soil management, fertilizer use, water quality and quantity, and chemical and physical soil characteristics (Schmitt et al., 2013). For instance, changes in OM contents, cation exchange capacity (CEC), $\mathrm{pH}$, ion dynamics, and aggregation occur when the soil is subjected to tillage and the incorporation of crop residues. Furthermore, the widespread use of phosphate fertilizers and cupric fungicides has increased the concentration of trace elements in vineyard soils, leading to transfer of these elements at toxic levels to humans and animals via the food chain (Fernández-Calviño et al., 2012; Wightwick et al., 2013). These changes become more evident as the length of the cultivation time in the area increases
(Preston et al., 2016). The concern is even greater for sandy soils due to their very low adsorption capacity for ions and pesticides.

Considering the fragile vineyard soils in the São Francisco Valley and the intensive agricultural system, multi-temporal studies to assess soil fertility changes are essential for soil sustainability. Most of the studies on vineyard soils were carried out in temperate and subtropical settlements and focused mainly on carbon balance, biomass production, and contamination of vineyard soils (Santos et al., 2013; Schmitt et al., 2013; Brunori et al., 2016). Additionally, data are very scarce for vineyard soil changes under cultivation in arid and semiarid regions. To fill this gap, this study assesses the changes in soil fertility in vineyard areas in the São Francisco Valley under different cultivation time spans using univariate and multivariate statistical analyses.

\section{Materials and Methods}

\subsection{Study area and experimental set-up}

Soil samples were collected in vineyards of Petrolina, Pernambuco State, Brazil. Geographic coordinates and soil classification for each area are shown in Figure 1. The climate is classified as Bswh' according to the Köppen classification. The annual average air temperature and rainfall are approximately $26^{\circ} \mathrm{C}$ and $541 \mathrm{~mm}$, respectively. The vineyards are irrigated using sprinklers and drip systems (Teixeira, 2010), and water quality is within the acceptable limits of salinity and sodicity.

The study area comprises five agricultural companies focused mainly on grape export (Colinas do Vale, Vale das Uvas, Fazenda Andorinha, Frutex and Fruit Fort), an experimental field from Embrapa Semiárido (EMBRAPA), and tenant farms with public irrigation projects (Bebedouro 1 and Bebedouro 2). These areas have different fertilization and liming records. In general, fertilization in agricultural companies annually contrib- 
utes $40 \mathrm{~m}^{3} \mathrm{ha}^{-1}$ of OM, $120 \mathrm{~kg} \mathrm{ha}^{-1}$ of N, $150 \mathrm{~kg} \mathrm{ha}^{-1}$ of $\mathrm{K}_{2} \mathrm{O}, 210 \mathrm{~kg} \mathrm{ha}^{-1}$ of $\mathrm{MgSO}_{4}$, and doses of $\mathrm{P}_{2} \mathrm{O}$ ranging from 100 to $200 \mathrm{~kg} \mathrm{ha}^{-1}$. In the Embrapa experimental field, $30 \mathrm{~m}^{3} \mathrm{ha}^{-1}$ of OM, $100 \mathrm{~kg} \mathrm{ha}^{-1}$ of $\mathrm{N}, 300 \mathrm{~kg} \mathrm{ha}^{-1}$ of $\mathrm{K}_{2} \mathrm{O}$ and $222 \mathrm{~kg} \mathrm{ha}^{-1} \mathrm{MgSO}_{4}$ are applied to the soil annually. Due to the high content of $\mathrm{P}$ in the soil, $\mathrm{P}$ fertilizer has not been applied in recent last years. On average, the tenant farmers apply less OM $\left(20 \mathrm{~m}^{3} \mathrm{ha}^{-1}\right)$. The annual amounts of other nutrients are $140 \mathrm{~kg} \mathrm{ha}^{-1}(\mathrm{~N})$,
$125 \mathrm{~kg} \mathrm{ha}^{-1}\left(\mathrm{P}_{2} \mathrm{O}_{5}\right), 230 \mathrm{~kg} \mathrm{ha}^{-1}\left(\mathrm{~K}_{2} \mathrm{O}\right)$, and $100 \mathrm{~kg} \mathrm{ha}^{-1}$ $\left(\mathrm{MgSO}_{4}\right)$. The application of lime occurred at a frequency defined by the need indicated by soil analysis and ranged from 500 to $1000 \mathrm{~kg} \mathrm{ha}^{-1}$. The $\mathrm{K}_{2} \mathrm{O}$ applications are especially high because this nutrient is among those in greatest demand by the vines. The addition of $\mathrm{MgSO}_{4}$ is necessary in these areas due to the high $\mathrm{Ca}$ contents, which necessitates adding ad-

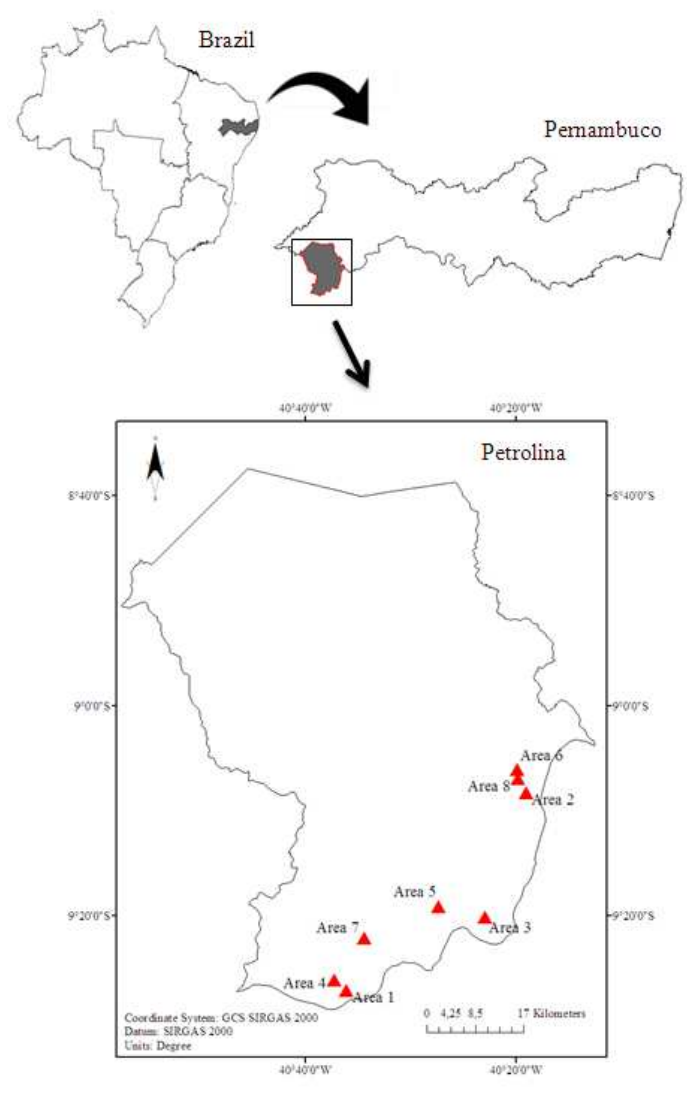

Figure 1. Geographic coordinates and soil classification for area of vineyards in Petrolina-Brazil. $1=$ Colinas do Vale - Typic Quartzipsamment; 2 = Embrapa - Ultisol Plinthic; 3 = Vale das Uvas - Typic Quartzipsamment; 4 = Fazenda Andorinha - Typic Quartzipsamment; 5 = Frutex - Typic Quartzipsamment; 6 = Bebedouro 1 - Ultisol Plinthic; 7 = Fruit Fort - Typic Quartzipsamment and $8=$ Bebedouro 2 - Ultisol Plinthic. 
equate $\mathrm{Mg}$ to enable the complex functions of proper soil exchange.

\subsection{Soil sampling}

Soil samples were collected from vineyards that had been in cultivation for $5,6,8,10,12,15,16$, and 30 years. Samples were collected from cultivated (CA - planting line) and reference areas (RA - Caatinga) at two depths (0-20 cm and 20-40 $\mathrm{cm}$ ). The reference areas (with no anthropogenic

Table 1. Chemical and physical analyses of soil samples from vineyard areas in Petrolina-Brazil.

\begin{tabular}{|c|c|c|c|c|c|c|c|c|}
\hline \multirow{2}{*}{ Parameters } & \multicolumn{8}{|c|}{ Vineyards } \\
\hline & 1 & 2 & 3 & 4 & 5 & 6 & 7 & 8 \\
\hline $\mathrm{pH}$ & 7.26 & 5.98 & 7.13 & 6.35 & 6.74 & 6.33 & 6.71 & 6.50 \\
\hline $\mathrm{P}\left(\mathrm{mg} \mathrm{dm}^{-3}\right)$ & 1035.05 & 238.31 & 378.73 & 535.59 & 374.87 & 76.98 & 290.34 & 248.36 \\
\hline $\mathrm{K}\left(\mathrm{cmol}_{\mathrm{c}} \mathrm{dm}^{-3}\right)$ & 0.27 & 0.26 & 0.30 & 0.23 & 0.49 & 0.44 & 0.18 & 0.46 \\
\hline $\mathrm{Ca}^{2+}\left(\mathrm{cmol}_{\mathrm{c}} \mathrm{dm}^{-3}\right)$ & 4.67 & 3.52 & 6.05 & 4.10 & 5.02 & 2.55 & 4.12 & 3.28 \\
\hline $\mathrm{Mg}^{2+}\left(\mathrm{cmol}_{\mathrm{c}} \mathrm{dm}^{-3}\right)$ & 1.32 & 1.00 & 1.73 & 1.60 & 1.52 & 1.13 & 1.68 & 1.08 \\
\hline $\mathrm{Al}^{2+}\left(\mathrm{cmol}_{\mathrm{c}} \mathrm{dm}^{-3}\right)$ & 0.05 & 0.13 & 0.00 & 0.08 & 0.07 & 0.07 & 0.07 & 0.05 \\
\hline $\mathrm{H}+\mathrm{Al}\left(\mathrm{cmol}_{\mathrm{c}} \mathrm{dm}^{-3}\right)$ & 0.69 & 0.85 & 0.93 & 1.79 & 1.02 & 1.29 & 0.96 & 1.07 \\
\hline $\mathrm{Na}^{+}\left(\mathrm{cmol}_{\mathrm{c}} \mathrm{dm}^{-3}\right)$ & 0.28 & 0.24 & 0.27 & 0.31 & 0.31 & 0.24 & 0.20 & 0.29 \\
\hline O.C. $\left(\mathrm{g} \mathrm{kg}^{-1}\right)$ & 9.15 & 10.23 & 10.47 & 13.32 & 10.05 & 6.41 & 9.84 & 7.34 \\
\hline O.M. $\left(\mathrm{g} \mathrm{kg}^{-1}\right)$ & 15.77 & 17.63 & 18.05 & 22.96 & 17.32 & 11.05 & 16.97 & 12.66 \\
\hline $\mathrm{CEC}_{\text {effective }}\left(\mathrm{cmol}_{\mathrm{c}} \mathrm{dm}^{-3}\right)$ & 6.59 & 5.15 & 8.36 & 6.32 & 7.40 & 4.43 & 6.25 & 5.17 \\
\hline $\mathrm{CEC}_{\text {total }}\left(\mathrm{cmol}_{\mathrm{c}} \mathrm{dm}^{-3}\right)$ & 7.22 & 5.87 & 9.29 & 8.03 & 8.35 & 5.66 & 7.14 & 6.19 \\
\hline $\mathrm{SB}\left(\mathrm{cmol}_{\mathrm{c}} \mathrm{dm}^{-3}\right)$ & 6.54 & 5.02 & 8.36 & 6.24 & 7.34 & 4.36 & 6.18 & 5.12 \\
\hline $\mathrm{V}(\%)$ & 90.40 & 84.67 & 89.84 & 77.90 & 87.76 & 77.47 & 86.68 & 82.68 \\
\hline m (\%) & 0.77 & 2.43 & 0.00 & 1.34 & 0.93 & 1.51 & 1.06 & 0.97 \\
\hline Sand $(\%)$ & 89.10 & 88.10 & 80.10 & 75.10 & 76.60 & 87.10 & 83.10 & 86.60 \\
\hline Silt (\%) & 4.00 & 5.00 & 9.00 & 10.00 & 10.50 & 5.00 & 5.00 & 5.50 \\
\hline Clay (\%) & 6.90 & 6.90 & 10.90 & 14.90 & 12.90 & 7.90 & 11.90 & 7.90 \\
\hline
\end{tabular}

1= Colinas do Vale; $2=$ Embrapa; $3=$ Vale das Uvas; 4=Fazenda Andorinha; $5=$ Frutex; 6= Bebedouro1; 7= Fruit Fort e 8= Bebedouro 2. O.C. = Organic carbon, O.M. = Organic matter; $\mathrm{CEC}=$ cation exchange capacity; $\mathrm{SB}=\mathrm{Sum}$ of bases, $\mathrm{V}(\%)=$ base saturation, $\mathrm{m}(\%)=$ Aluminum saturation percentage.

interference) presented the same soils and were adjacent to the vineyards. Chemical and physical analyses of the cultivated areas are shown in Table 1.
Three composite soil samples were collected from each vineyard and reference area. For sampling, the cultivated area was divided into three subareas. In each subarea, 20 samples were taken randomly from 
the planting row. These samples were them mixed up to form a composite sample. A similar procedure was carried out in the reference areas.

\subsection{Chemical and physical analyses}

The samples were air dried and passed through a 2-mm sieve. The chemical characteristics analyzed were the $\mathrm{pH}$ in water; exchangeable $\mathrm{K}^{+}$and $\mathrm{Na}^{+}$ by flame emission photometry after extraction with Mehlich-1; exchangeable $\mathrm{Ca}^{2+}, \mathrm{Mg}^{2+}$, and $\mathrm{Al}^{3+}$ by titration after extraction with $1 \mathrm{~mol} \mathrm{~L}^{-1} \mathrm{KCl}$ solution; $\mathrm{H}+\mathrm{Al}$ by titration after extraction with a $0.5 \mathrm{~mol} \mathrm{~L}^{-1}$ calcium acetate solution; and available $\mathrm{P}$ by colorimetry after extraction with Mehlich-1 (Embrapa, 2011). Organic carbon (OC) was determined by the Walkley-Black method. The results obtained from the sorptive complex were used to calculate the values for the sum of bases (SB), total $(\mathrm{T})$ and effective $(\mathrm{t})$ cation exchange capacity, base saturation ( $\mathrm{V} \%)$, and $\mathrm{Al}$ saturation $(\mathrm{m} \%)$. The particle size of soil samples was analyzed using the densimeter method as described by Embrapa (2011).

\subsection{Statistical analysis}

The study was conducted with an $8 \times 2 \times 2$ factorial design (eight cultivation times, two environments, and two depths) with three repetitions, totaling 96 experimental units. The experimental results were analyzed by applying an $\mathrm{F}$ test to the analysis of variance (ANOVA), as well as correlation analyses, and Tukey's test $(\mathrm{P}<0.05)$. The results were also assessed by discriminant analysis (DA) and factor analysis (FA). By analyzing sev- eral correlated variables, the DA enabled further comparison between the cultivated and reference areas. Furthermore, FA was applied to verify the soil characteristics related to the downward movement of P. All multivariate statistical analyses were performed with XLSTAT statistical software (version 2014.5.03).

\section{Results and Discussion}

There was a significant difference $(\mathrm{P}<0.05)$ in $\mathrm{OM}$ content between the cultivated areas and the reference areas for most of the analyzed cultivation times (Table 2). The highest OM contents occurred in the areas under cultivation for $5,8,10,12$, and 16 years at depths of $0-20 \mathrm{~cm}$ and in the areas under cultivation for $8,10,12$, and 16 years at depths of $20-40 \mathrm{~cm}$.

In areas under different vineyard cultivation times in the São Francisco Valley region, Faria et al. (2007) found an increase in OM content compared to areas with no anthropogenic interference. This effect is beneficial for the region, given the very low OM content originally found in the soil (Table 2). Organic matter is important for soil structure, nutrient retention, and thus for the quality of the sandy soils from this region. As expected, there was a reduction in the organic matter content with increasing depth in both the cultivated areas and in the reference areas. Preston et al. (2016) observed high positive correlation $(\mathrm{p}<0.01)$ between organic matter and $\mathrm{Cu}$ in the same studied region, which indicate the low mobility of $\mathrm{Cu}$ in the soil. Furthermore, the positive correlation between $\mathrm{Cu}$ and organic matter shows that OM probably act as a main metal reservoir in vineyard soils (Duplay 
Table 2. Averages fertility soil attributes evaluated of cultivated areas (CA) and caatinga (RA) in different cultivation times (CT) and at two depths $(0-20$ and $20-40 \mathrm{~cm})$.

\begin{tabular}{|c|c|c|c|c|c|c|c|c|c|c|c|c|c|c|c|c|c|c|c|c|}
\hline \multirow{2}{*}{$\begin{array}{c}\text { CT } \\
\text { Years }\end{array}$} & \multicolumn{2}{|c|}{$\begin{array}{l}\mathrm{OM} \\
(\%)\end{array}$} & \multicolumn{2}{|c|}{$\begin{array}{c}\mathrm{P} \\
\left(\mathrm{mg} \mathrm{dm}^{-3}\right)\end{array}$} & \multicolumn{2}{|c|}{$\mathrm{Ca}$} & \multicolumn{2}{|c|}{$\overline{\mathrm{Mg}}$} & \multicolumn{2}{|c|}{$\mathrm{Na}$} & \multicolumn{2}{|c|}{$\begin{array}{c}\mathrm{K} \\
\left(\mathrm{cmol}_{\mathrm{c}} \mathrm{dm}^{-3}\right)\end{array}$} & \multicolumn{2}{|c|}{$\mathrm{H}+\mathrm{Al}$} & \multicolumn{2}{|c|}{ CEC } & \multicolumn{2}{|c|}{ SB } & \multicolumn{2}{|c|}{$\begin{array}{c}\mathrm{V} \\
(\%)\end{array}$} \\
\hline & $\mathrm{CA}$ & RA & $\mathrm{CA}$ & RA & $\mathrm{CA}$ & RA & $\mathrm{CA}$ & RA & $\mathrm{CA}$ & RA & $\mathrm{CA}$ & RA & $\mathrm{CA}$ & RA & $\mathrm{CA}$ & RA & $\mathrm{CA}$ & RA & $\mathrm{CA}$ & RA \\
\hline & \multicolumn{20}{|c|}{$0-20 \mathrm{~cm}$} \\
\hline 5 & $5.77 \mathrm{a}$ & $5.69 \mathrm{~b}$ & $1035.05 \mathrm{a}$ & $6.50 \mathrm{~b}$ & $4.67 \mathrm{a}$ & $1.10 \mathrm{~b}$ & $1.32 \mathrm{a}$ & $0.43 \mathrm{~b}$ & $0.28 \mathrm{a}$ & $0.19 b$ & $0.27 \mathrm{a}$ & $0.05 \mathrm{~b}$ & $0.69 \mathrm{a}$ & $0.66 \mathrm{a}$ & $7.22 \mathrm{a}$ & $2.43 b$ & $6.54 \mathrm{a}$ & $1.77 \mathrm{~b}$ & $90 \mathrm{a}$ & $72 b$ \\
\hline 6 & $17.63 \mathrm{a}$ & $12.18 \mathrm{a}$ & 238.31a & $5.04 \mathrm{~b}$ & $3.52 \mathrm{a}$ & $2.33 \mathrm{a}$ & $1.00 \mathrm{a}$ & $0.73 a$ & $0.24 \mathrm{a}$ & $0.24 \mathrm{a}$ & $0.26 \mathrm{a}$ & $0.28 \mathrm{a}$ & $0.85 \mathrm{a}$ & $0.94 \mathrm{a}$ & $5.87 \mathrm{a}$ & $4.53 \mathrm{a}$ & $5.02 \mathrm{a}$ & $3.59 \mathrm{a}$ & $84 a$ & $79 a$ \\
\hline 8 & $18.05 \mathrm{a}$ & $9.00 \mathrm{~b}$ & $378.73 a$ & $11.38 \mathrm{~b}$ & $6.05 \mathrm{a}$ & $1.35 \mathrm{~b}$ & $1.73 a$ & $0.67 \mathrm{~b}$ & $0.27 \mathrm{a}$ & $0.23 a$ & $0.30 \mathrm{a}$ & $0.23 \mathrm{~b}$ & $0.93 \mathrm{~b}$ & $3.08 \mathrm{a}$ & $9.29 \mathrm{a}$ & $5.56 \mathrm{~b}$ & $8.36 a$ & $2.48 \mathrm{~b}$ & $89 a$ & $44 \mathrm{~b}$ \\
\hline 10 & $2.96 \mathrm{a}$ & $7.21 \mathrm{~b}$ & $535.59 \mathrm{a}$ & $3.00 \mathrm{~b}$ & $4.10 \mathrm{a}$ & $0.68 \mathrm{~b}$ & $1.60 \mathrm{a}$ & $0.35 b$ & $0.31 \mathrm{a}$ & $0.21 \mathrm{a}$ & $0.23 \mathrm{a}$ & $0.05 \mathrm{~b}$ & $1.79 \mathrm{a}$ & $1.21 \mathrm{a}$ & $8.03 \mathrm{a}$ & $2.51 \mathrm{~b}$ & $6.24 a$ & $1.30 \mathrm{~b}$ & $77 a$ & $51 \mathrm{~b}$ \\
\hline 12 & $.32 \mathrm{a}$ & $7.37 \mathrm{~b}$ & $374.87 \mathrm{a}$ & $189.2 \mathrm{~b}$ & $5.02 \mathrm{a}$ & $3.35 \mathrm{~b}$ & $1.52 \mathrm{a}$ & $1.37 \mathrm{a}$ & $0.31 \mathrm{a}$ & $0.24 \mathrm{a}$ & $0.49 \mathrm{a}$ & $0.57 \mathrm{a}$ & $1.02 \mathrm{a}$ & $0.58 \mathrm{a}$ & $8.35 \mathrm{a}$ & $6.10 \mathrm{~b}$ & $7.34 \mathrm{a}$ & $.53 \mathrm{~b}$ & $87 a$ & $90 \mathrm{a}$ \\
\hline 15 & $11.05 \mathrm{~b}$ & $15.37 \mathrm{a}$ & $.98 \mathrm{a}$ & $3.20 \mathrm{~b}$ & $2.55 \mathrm{a}$ & $1.83 \mathrm{~b}$ & $1.13 \mathrm{a}$ & $0.53 \mathrm{a}$ & $0.24 \mathrm{a}$ & $0.24 \mathrm{a}$ & $0.44 a$ & $0.26 \mathrm{~b}$ & $1.29 \mathrm{~b}$ & $2.20 \mathrm{a}$ & $5.66 \mathrm{a}$ & $5.07 \mathrm{a}$ & $4.36 \mathrm{a}$ & $2.87 \mathrm{~b}$ & $77 a$ & $56 \mathrm{~b}$ \\
\hline 16 & $16.97 \mathrm{a}$ & $7.79 \mathrm{~b}$ & $290.34 \mathrm{a}$ & $2.00 \mathrm{~b}$ & $4.12 \mathrm{a}$ & $1.83 \mathrm{~b}$ & $1.68 \mathrm{a}$ & $0.73 b$ & $0.20 \mathrm{a}$ & $0.22 \mathrm{a}$ & $0.18 \mathrm{a}$ & $0.15 \mathrm{a}$ & $0.96 \mathrm{~b}$ & $1.65 \mathrm{a}$ & $7.14 a$ & $4.58 \mathrm{~b}$ & $6.18 \mathrm{a}$ & $2.93 \mathrm{~b}$ & $86 a$ & $63 b$ \\
\hline \multirow[t]{2}{*}{30} & $12.66 \mathrm{~b}$ & $15.37 \mathrm{a}$ & $248.36 \mathrm{a}$ & $3.20 \mathrm{~b}$ & $3.28 \mathrm{a}$ & $1.83 \mathrm{~b}$ & $1.08 \mathrm{a}$ & $0.53 \mathrm{a}$ & $.29 \mathrm{a}$ & $0.24 a$ & $0.46 \mathrm{a}$ & $0.26 \mathrm{~b}$ & $1.07 \mathrm{~b}$ & $2.20 \mathrm{a}$ & $6.19 \mathrm{a}$ & $5.07 \mathrm{~b}$ & $5.12 \mathrm{a}$ & $2.87 \mathrm{~b}$ & $82 a$ & $56 \mathrm{~b}$ \\
\hline & \multicolumn{20}{|c|}{$20-40 \mathrm{~cm}$} \\
\hline 5 & $9.83 \mathrm{a}$ & $5.39 \mathrm{a}$ & $467.35 \mathrm{a}$ & $2.97 \mathrm{~b}$ & $3.00 \mathrm{a}$ & $0.82 \mathrm{~b}$ & $1.00 \mathrm{a}$ & $0.27 \mathrm{~b}$ & $0.25 \mathrm{a}$ & $0.20 \mathrm{~b}$ & $0.22 \mathrm{a}$ & $0.06 \mathrm{~b}$ & $0.25 \mathrm{~b}$ & $0.80 \mathrm{a}$ & $4.72 \mathrm{a}$ & $2.14 \mathrm{~b}$ & $4.47 \mathrm{a}$ & $1.34 \mathrm{~b}$ & $94 a$ & $62 \mathrm{~b}$ \\
\hline 6 & $11.15 \mathrm{a}$ & $8.13 \mathrm{a}$ & $179.98 \mathrm{a}$ & $2.59 \mathrm{~b}$ & $2.13 a$ & $2.02 \mathrm{a}$ & $0.63 \mathrm{a}$ & $0.45 \mathrm{a}$ & $0.23 a$ & $0.21 \mathrm{a}$ & $0.23 \mathrm{a}$ & $0.25 \mathrm{a}$ & $1.60 \mathrm{a}$ & $0.91 \mathrm{~b}$ & $4.83 \mathrm{a}$ & $3.84 \mathrm{a}$ & $3.23 \mathrm{a}$ & $2.93 \mathrm{a}$ & $66 \mathrm{~b}$ & $76 a$ \\
\hline 8 & $11.49 \mathrm{a}$ & $5.34 \mathrm{~b}$ & $325.66 a$ & $5.31 \mathrm{~b}$ & $4.92 \mathrm{a}$ & $0.92 b$ & $1.20 \mathrm{a}$ & $0.65 \mathrm{a}$ & $0.28 \mathrm{a}$ & $0.22 \mathrm{~b}$ & $0.26 a$ & $0.24 \mathrm{a}$ & $0.33 b$ & $2.72 a$ & $6.98 \mathrm{a}$ & $4.75 \mathrm{~b}$ & $6.65 \mathrm{a}$ & $2.03 \mathrm{~b}$ & $95 a$ & $42 \mathrm{~b}$ \\
\hline 10 & $20.72 \mathrm{a}$ & $6.51 \mathrm{~b}$ & $827.75 \mathrm{a}$ & $2.04 \mathrm{~b}$ & $4.50 \mathrm{a}$ & $0.38 \mathrm{~b}$ & $1.98 \mathrm{a}$ & $0.33 \mathrm{~b}$ & $0.36 \mathrm{a}$ & $0.19 \mathrm{~b}$ & $0.25 \mathrm{a}$ & $0.04 \mathrm{~b}$ & $0.88 \mathrm{~b}$ & $1.05 \mathrm{a}$ & $7.97 \mathrm{a}$ & $1.99 \mathrm{~b}$ & $7.09 \mathrm{a}$ & $0.94 \mathrm{~b}$ & $88 \mathrm{a}$ & $47 \mathrm{~b}$ \\
\hline 12 & $11.38 \mathrm{a}$ & $4.78 \mathrm{~b}$ & 197.18a & $140.8 \mathrm{a}$ & $3.62 \mathrm{a}$ & $2.82 \mathrm{~b}$ & $1.42 \mathrm{a}$ & $1.15 \mathrm{a}$ & $0.28 \mathrm{a}$ & $0.25 \mathrm{a}$ & $0.39 \mathrm{a}$ & $0.38 \mathrm{a}$ & $1.07 \mathrm{a}$ & $0.55 \mathrm{a}$ & $6.77 \mathrm{a}$ & $5.15 \mathrm{~b}$ & $5.70 \mathrm{a}$ & $4.60 \mathrm{a}$ & $83 a$ & $89 a$ \\
\hline 15 & $8.32 \mathrm{~b}$ & $13.76 \mathrm{a}$ & $50.64 \mathrm{a}$ & $1.10 \mathrm{~b}$ & $2.63 a$ & $1.73 \mathrm{~b}$ & $1.23 \mathrm{a}$ & $1.08 \mathrm{a}$ & $0.25 \mathrm{a}$ & $0.24 a$ & $0.39 \mathrm{a}$ & $0.28 b$ & $1.32 \mathrm{~b}$ & $2.64 a$ & $5.83 \mathrm{a}$ & $5.98 \mathrm{a}$ & $4.5 \mathrm{la}$ & $3.34 \mathrm{~b}$ & $77 a$ & $55 \mathrm{~b}$ \\
\hline 16 & $12.26 \mathrm{a}$ & $5.20 \mathrm{~b}$ & $321.72 \mathrm{a}$ & $1.02 \mathrm{~b}$ & $3.58 \mathrm{a}$ & $1.67 \mathrm{~b}$ & $1.55 \mathrm{a}$ & $0.62 b$ & $0.22 \mathrm{a}$ & $0.20 \mathrm{a}$ & $0.15 \mathrm{a}$ & $0.18 \mathrm{a}$ & $0.69 \mathrm{~b}$ & $2.12 \mathrm{a}$ & $6.19 \mathrm{a}$ & $4.79 \mathrm{a}$ & $5.50 \mathrm{a}$ & $2.67 \mathrm{~b}$ & $89 a$ & $55 \mathrm{~b}$ \\
\hline 30 & $9.72 \mathrm{~b}$ & $13.76 \mathrm{a}$ & $39.65 a$ & $1.10 \mathrm{~b}$ & $3.15 \mathrm{a}$ & $1.73 \mathrm{~b}$ & $1.07 \mathrm{a}$ & $1.08 \mathrm{a}$ & $0.27 a$ & $0.24 a$ & $0.42 \mathrm{a}$ & $0.28 b$ & $1.24 \mathrm{~b}$ & $2.64 a$ & $6.14 a$ & $5.98 \mathrm{a}$ & $4.90 \mathrm{a}$ & $3.34 \mathrm{~b}$ & $79 a$ & $55 \mathrm{~b}$ \\
\hline
\end{tabular}

Means followed by same letter (between CA and RA for the same attribute and depth) not differ significantly by Tukey test $(\mathrm{P}<0.05)$

et al., 2014; Gómez-Armesto et al., 2015). This fact might ameliorate vineyard soils of a semiarid region known as the largest center of irrigated fruit production in Brazil.

There was no significant difference in the OM contents in the area cultivated for 6 years at all depths (Table 2). This may be related to the fact that this is an experimental area of Embrapa Semiárido, and the amounts of added manure and plant residues are lower than those regularly used in areas belonging to export companies. There was also no significant difference in the OM content in the area under cultivation for 5 years at depths of 20-40 cm (Table 2). This may be due to the more recent application of manure, which would not have been mineralized, resulting in limited mobilization towards subsurface layers.
Areas under cultivation for 15 and 30 years had higher OM values for both depths than the reference areas (Table 2). These areas belong to a tenant farmer from the Bebedouro Irrigation Project who grows the Italia variety for the domestic market. Thus, this farmer does not make great investments in the vineyards and uses lower annual amounts of OM $\left(20 \mathrm{~m}^{3} \mathrm{ha}^{-1}\right)$ compared to agricultural companies $\left(40 \mathrm{~m}^{3} \mathrm{ha}^{-1}\right)$ and Embrapa $\left(40 \mathrm{~m}^{3} \mathrm{ha}^{-1}\right)$. Under such manure management, soil cultivation had negative effects on the already low OM contents. Cavalcante et al. (2007) report that conventional tillage systems showed a reduction in OM content, probably because of inadequate management (for example, the removal of leaves that fall during senescence or during pruning). On the other hand, Almeida et al. (2005) found higher OM contents in a non-tillage 
system due to the greater diversity of plant species and the probably higher carbon recycling provided by continued replacement of organic plant material.
OM content presented positive and highly significant correlations with $\mathrm{Ca}, \mathrm{Mg}, \mathrm{CEC}$, and $\mathrm{SB}$ at depths of $0-20 \mathrm{~cm}$ and with $\mathrm{P}, \mathrm{Ca}, \mathrm{Mg}, \mathrm{Na}, \mathrm{CEC}$, and SB at $20-40 \mathrm{~cm}$ for the cultivated areas (Table

Table 3. Pearson's correlation matrix for chemical analysis vineyard areas in Petrolina-Brazil

\begin{tabular}{|c|c|c|c|c|c|c|c|c|c|}
\hline & Sites & $\mathrm{pH}$ & $\begin{array}{c}\mathrm{OM} \\
\mathrm{g} \mathrm{kg}^{-1}\end{array}$ & $\begin{array}{c}\mathrm{P} \\
\mathrm{mg} \mathrm{dm}^{-3}\end{array}$ & $\mathrm{Ca}$ & $\mathrm{Mg}$ & $\begin{array}{c}\mathrm{Na} \\
\mathrm{cmol}_{\mathrm{c}} \mathrm{dm}^{-3}\end{array}$ & $\mathrm{~K}$ & $\mathrm{H}+\mathrm{Al}$ \\
\hline & & & \multicolumn{7}{|c|}{$0-20 \mathrm{~cm}$} \\
\hline \multirow[t]{2}{*}{ OM } & $\mathrm{CA}$ & -0.16 & - & 0.35 & $0.55 * *$ & $0.58 * *$ & 0.32 & -0.38 & 0.3 \\
\hline & RA & -0.36 & - & -0.28 & 0.17 & -0.15 & $0.42 *$ & 0.23 & $0.46^{*}$ \\
\hline \multirow[t]{2}{*}{$\mathrm{P}$} & $\mathrm{CA}$ & $0.47^{*}$ & 0.35 & - & $0.46^{*}$ & 0.25 & 0.34 & -0.28 & -0.15 \\
\hline & $\mathrm{RA}$ & $0.55^{* *} *$ & -0.28 & - & $0.75 * *$ & $0.75 * *$ & 0.17 & $0.81 *$ & $-0.43^{*}$ \\
\hline \multirow[t]{2}{*}{$\mathrm{Ca}$} & $\mathrm{CA}$ & $0.53 * *$ & $0.55 * *$ & $0.46^{*}$ & - & $0.62 * *$ & 0.30 & -0.15 & -0.25 \\
\hline & RA & $0.47^{*}$ & 0.18 & $0.75 * *$ & - & $0.72 * *$ & $0.42^{*}$ & $0.86^{* *}$ & -0.29 \\
\hline \multirow[t]{2}{*}{$\mathrm{Mg}$} & $\mathrm{CA}$ & 0.32 & $0.58 * *$ & 0.25 & $0.62^{* *} *$ & - & 0.23 & -0.19 & 0.01 \\
\hline & $\mathrm{RA}$ & 0.34 & -0.15 & $0.75 * *$ & $0.72 * *$ & - & 0.25 & $0.74 * *$ & -0.25 \\
\hline \multirow[t]{2}{*}{$\mathrm{K}$} & $\mathrm{CA}$ & 0.01 & -0.38 & -0.28 & -0.15 & -0.19 & $0.44 *$ & - & -0.03 \\
\hline & $\mathrm{RA}$ & 0.29 & 0.23 & $0.81 * *$ & $0.86^{* *}$ & $0.74 * *$ & $0.45^{*}$ & - & -0.10 \\
\hline \multirow[t]{2}{*}{$\mathrm{H}+\mathrm{Al}$} & $\mathrm{CA}$ & $-0.47^{*}$ & 0.30 & -0.15 & -0.25 & 0.01 & 0.05 & -0.03 & - \\
\hline & $\mathrm{RA}$ & $-0.94 * *$ & $0.46^{*}$ & $-0.43^{*}$ & -0.29 & -0.25 & 0.14 & -0.10 & - \\
\hline \multirow[t]{2}{*}{ CEC } & $\mathrm{CA}$ & 0.38 & $0.68 * *$ & 0.38 & $0.90 * *$ & $0.78 * *$ & $0.40^{*}$ & -0.07 & 0.10 \\
\hline & $\mathrm{RA}$ & -0.20 & $0.40^{*}$ & $0.49 *$ & $0.74 * *$ & $0.65 * *$ & $0.50 * *$ & $0.80 * *$ & 0.40 \\
\hline \multirow[t]{2}{*}{ SB } & $\mathrm{CA}$ & $0.52^{* *} *$ & $0.58 * *$ & $0.42 *$ & $0.97 * *$ & $0.77 * *$ & 0.38 & -0.06 & -0.21 \\
\hline & RA & $0.43^{*}$ & 0.11 & $0.81 * *$ & $0.97 * *$ & $0.86^{* *} *$ & $0.43^{*}$ & $0.91 * *$ & -0.27 \\
\hline \multirow[t]{3}{*}{ V } & $\mathrm{CA}$ & $0.60 * *$ & 0.10 & 0.39 & $0.63 * *$ & 0.39 & 0.12 & -0.08 & $-0.87 * *$ \\
\hline & $\mathrm{RA}$ & $0.90^{* * *}$ & -0.23 & $0.66 * *$ & $0.73^{* *}$ & $0.62 * *$ & 0.12 & $0.54 * *$ & $-0.82 * *$ \\
\hline & & & \multicolumn{7}{|c|}{$20-40 \mathrm{~cm}$} \\
\hline \multirow[t]{2}{*}{$\mathrm{OM}$} & $\mathrm{CA}$ & -0.08 & - & $0.76 * *$ & $0.57 * *$ & $0.57 * *$ & $0.51 * *$ & -0.13 & 0.01 \\
\hline & RA & $-0.46^{*}$ & - & -0.32 & 0.16 & 0.29 & 0.30 & 0.29 & $0.50^{* *} *$ \\
\hline \multirow[t]{2}{*}{$\mathrm{P}$} & $\mathrm{CA}$ & 0.33 & $0.76^{* *}$ & - & $0.54 * *$ & $0.63 * *$ & $0.57 * *$ & $-0.42 *$ & $-0.42 *$ \\
\hline & $\mathrm{RA}$ & $0.63 * *$ & -0.32 & - & $0.67 * *$ & $0.38^{*}$ & 0.35 & $0.57 * *$ & $-0.48^{*}$ \\
\hline \multirow[t]{2}{*}{$\mathrm{Ca}$} & $\mathrm{CA}$ & $0.48 * *$ & $0.57 * *$ & $0.54 * *$ & - & $0.57 * *$ & $0.46^{*}$ & -0.06 & -0.48 \\
\hline & $\mathrm{RA}$ & 0.38 & 0.16 & $0.67 * *$ & - & $0.51 * *$ & $0.54 * *$ & $0.85 * *$ & -0.13 \\
\hline \multirow[t]{2}{*}{$\mathrm{Mg}$} & $\mathrm{CA}$ & 0.16 & $0.57 * *$ & $0.63 * *$ & $0.57 * *$ & - & $0.55^{* *} *$ & -0.01 & -0.27 \\
\hline & $\mathrm{RA}$ & -0.13 & 0.29 & 0.38 & $0.51 * *$ & - & $0.48^{*}$ & $0.67 * *$ & 0.37 \\
\hline \multirow[t]{2}{*}{$\mathrm{K}$} & $\mathrm{CA}$ & -0.37 & -0.14 & $-0.42 *$ & -0.06 & -0.01 & 0.22 & - & 0.37 \\
\hline & $\mathrm{RA}$ & -0.01 & 0.29 & $0.57 * *$ & $0.85^{* *}$ & $0.67 * *$ & $0.73 * *$ & - & 0.24 \\
\hline \multirow[t]{2}{*}{$\mathrm{H}+\mathrm{Al}$} & $\mathrm{CA}$ & $-0.94 * *$ & 0.01 & $-0.41 *$ & $-0.48^{*}$ & -0.27 & -0.20 & 0.37 & - \\
\hline & RA & $-0.92 * *$ & $0.50^{* *} *$ & $-0.48^{*}$ & -0.13 & 0.37 & 0.27 & 0.24 & - \\
\hline \multirow[t]{2}{*}{ CEC } & $\mathrm{CA}$ & 0.01 & $0.70^{* *}$ & $0.49 *$ & $0.84 * *$ & $0.75 * *$ & $0.57 * *$ & 0.21 & 0.03 \\
\hline & RA & $-0.40^{*}$ & $0.49 *$ & 0.20 & $0.63 * *$ & $0.81 * *$ & $0.63 * *$ & $0.84 * *$ & $0.68 * *$ \\
\hline \multirow[t]{2}{*}{ SB } & $\mathrm{CA}$ & 0.39 & $0.63 * *$ & $0.61 * *$ & $0.95 * *$ & $0.79 * *$ & $0.59 * *$ & 0.03 & $-0.43^{*}$ \\
\hline & RA & 0.19 & 0.25 & $0.64 * *$ & $0.93 * *$ & $0.78 * *$ & $0.62 * *$ & $0.91 * *$ & 0.08 \\
\hline \multirow[t]{2}{*}{$\mathrm{V}$} & $\mathrm{CA}$ & $0.91 * *$ & 0.14 & $0.51 * *$ & $0.68 * *$ & $0.47^{*}$ & 0.31 & -0.25 & $-0.94 * *$ \\
\hline & RA & $0.82 * *$ & -0.17 & $0.74 * *$ & $0.79 * *$ & 0.26 & 0.26 & $0.49 *$ & $-0.66^{* *} *$ \\
\hline
\end{tabular}

** and * are significant correlations at $\mathrm{p}<0.01$ and $\mathrm{p}<0.05$, respectively. 
3). OM has a major role in the cycling of most nutrients, in addition to helping enhance the CEC of tropical soils. For the naturally low fertility and low OM soils of São Francisco Valley, inputs of organic materials are an essential part of the system sustainability.

The correlation between $\mathrm{OM}$ and $\mathrm{P}$ at $20-40 \mathrm{~cm}$ in the cultivated areas is probably due to the application of $\mathrm{P}$ in the form of manure and other organic sources that are prone to transport P into the subsoil. The regular use of animal manure, root exudation, and the metabolism of microorganisms can continuously maintain the blocking process of $\mathrm{P}$ adsorption sites. Organic acids with a high molecular mass (humic and fulvic acids) remain in soil longer and are more effective in the complexation of toxic elements such as Al. Therefore, these compounds can be more important than low-molecular-mass organic acids in the inhibition of $\mathrm{P}$ adsorption in soil (Pavinato and Rosolem, 2008). Furthermore, the cover crop provided during long-term cultivation changed the soil $\mathrm{P}$ dynamics as well. It occurs mainly due to P recycling mobilized into crop residues and the colonization of microorganism mobilizers of $\mathrm{P}$ in the rhizosphere (Tiecher et al., 2015).

High levels of available $\mathrm{P}$ were found in soils (Table 2) due to the cumulative effects of high rates of $P$ applied via fertirrigation. Environmentally speaking, phosphate fertilizers have been widely used to ameliorate soils contaminated with $\mathrm{Pb}$ due to their strong affinity (Lin et al., 2005). However, the sandy soils of the study areas (Table 1) present a very low capacity for $\mathrm{P}$ adsorption. The high mobility of phosphates in the soil profile given the increased values found in the subsoil indicate that the maximum $\mathrm{P}$ adsorption is easily met. Considering the nearness of the vineyards to the São Francisco river, problems related to eutrophication must be kept in mind. In other words, phosphate fertilizers applied in soils from this semi- arid region exceeded the plant demand and part of this amount may reach the water resources owing to the sandy texture and low Fe oxide content (Preston et al., 2016).

The $\mathrm{P}$ concentration in soils was significantly different between the reference and cultivated areas in both soil layers (Table 2). Values for available P are extremely high in the cultivated areas. It is unlikely that soils with such high values of available $\mathrm{P}$ would be responsive to $\mathrm{P}$ fertilization. For instance, the areas under cultivation for 5 and 10 years showed $\mathrm{P}$ values of up to 1035 and $535 \mathrm{mg} \mathrm{dm}^{-3}$, respectively. $\mathrm{P}$ contents in these soils were 159 and 178 times greater than those in the reference areas. At depths of $20-40 \mathrm{~cm}, \mathrm{P}$ values in these areas were 157 and 405 times as high as those measured in the reference areas, which is consistent with the large amounts of $\mathrm{P}$ prone to leaching. These two areas belong to large companies that apply large amounts of mineral fertilizers, agrochemicals, and other agricultural inputs. The high amount of $\mathrm{P}$ was due to the cumulative effects of the high $\mathrm{P}$ rates applied via irrigation in this region. Even sandy soils can accumulate high amounts of $\mathrm{P}$ by either $\mathrm{P}$ adsorption or precipitation in case long-term and successive phosphate fertilization is used (Schmitt et al. 2013). The leaching of $\mathrm{P}$ is also very high in these soils, being essential to reduce $\mathrm{P}$ inputs.

$\mathrm{Ca}$ contents in cultivated areas were significantly different from those in the reference areas at the two depths analyzed, with greater values found in cultivated areas (Table 2). This increase may have occurred because of liming and the use of superphosphates (calcium phosphates). In an area cultivated with vines for 12 years in the lower-middle region of the São Francisco River, Faria et al. (2007) also found higher $\mathrm{Ca}$ values in the cultivated areas compared to soil with Caatinga vegetation. Almeida et al. (2005) found considerably lower $\mathrm{Mg}$ and $\mathrm{Ca}$ contents in an uncultivated field than in conventional planting areas 
because the uncultivated field was not subjected to liming and fertilization.

The $\mathrm{Mg}$ contents indicated significant differences between the analyzed environments in the areas under cultivation for $5,8,10$, and 16 years at a depths of $0-20 \mathrm{~cm}$ and in areas under cultivation for 5,10 , and 16 years at depths of $20-40 \mathrm{~cm}$. However, the highest values were always observed in cultivated areas (Table 2). This change may be due to the effect of liming, which increases $\mathrm{Ca}$ and $\mathrm{Mg}$ content and reduces $\mathrm{H}+\mathrm{Al}$ content in soil. In this region, the use of magnesium sulfate is common in both soil and foliar fertilization.

$\mathrm{Ca}$ and $\mathrm{Mg}$ values similar to those found at $0-20$ $\mathrm{cm}$ in the cultivated and reference areas were also observed at $20-40 \mathrm{~cm}$ in the two analyzed environments (Table 2). This was probably due to the organic complexation of these cations and their subsequent movement into subsurface. According to Franchini et al. (2001), the movement of $\mathrm{Ca}$ and $\mathrm{Mg}$ can be explained by organic complexation of these cations; however, this complexation also depends on the plant residues in the soil surface. The decomposition of plant residues from the soil surface gives rise to water-soluble organic compounds, which have been known to be responsible for the complexation of $\mathrm{Ca}$ in surface layers, followed by migration in the soil profile (Gatiboni et al., 2003). These $\mathrm{Ca}$ and $\mathrm{Mg}$ contents in the subsurface could also have occurred due to the sandy texture of the soil and the low cation retention capacity in the study areas (Table 1), which left cations free in solution.

In general, $\mathrm{K}$ contents differed significantly $(\mathrm{P}<0.05)$ between the cultivated and reference areas for both depths (Table 2). The areas under cultivation for 6 , 12 , and 16 years at depths of $0-20 \mathrm{~cm}$ and the area cultivated for 8 years at depths of $20-40 \mathrm{~cm}$ did not show significant differences from the reference areas. Similar K values were found at the two depth ranges analyzed, probably because the rainfall in the region exceeded $100 \mathrm{~mm}$ when soil samples were collected for the study. Therefore, these high $\mathrm{K}$ values at depths of 20-40 cm were due to leaching of $\mathrm{K}$ that resulted from the high rainfall and the low CEC of soils. Faria et al. (2007) obtained similar results. Highly significant positive correlations were observed between $\mathrm{pH}, \mathrm{Ca}, \mathrm{SB}$, and $\mathrm{V} \%(0.52-0.60, \mathrm{P}<0.01)$ at depths of $0-20 \mathrm{~cm}$ and between $\mathrm{pH}$ and $\mathrm{Ca}$ and $\mathrm{V} \%$ $(0.48-0.91, \mathrm{P}<0.01)$ at depths of $20-40 \mathrm{~cm}$ for the cultivated areas. Such correlations were also observed for $\mathrm{pH}, \mathrm{P}$, and $\mathrm{V} \%$ for the reference areas at both depths analyzed. A significantly negative correlation was also observed between $\mathrm{pH}$ and $\mathrm{H}+\mathrm{Al}$ for the cultivated and reference areas at both depths (-0.47 $(\mathrm{P}<0.05),-0.94(\mathrm{P}<0.01),-0.94(\mathrm{P}<0.01)$, and -0.92 $(\mathrm{P}<0.01)$, respectively; Table 3). Araújo et al. (2000) found a similar correlation for $\mathrm{pH}$ and $\mathrm{Ca}$ in soils cultivated with cassava and in native forest. Overall, the $\mathrm{pH}$ values of reference areas were lower than those of cultivated areas (Table 1).

The CEC values significantly differed $(\mathrm{P}<0.05)$ in areas under cultivation for $5,8,10,12,16$, and 30 years at depths of $0-20 \mathrm{~cm}$, while at depths of $20-40 \mathrm{~cm}$, only the areas under cultivation for $5,8,10$, and 12 years showed higher values in relation to the reference area (Table 2). Faria et al. (2004) observed an increase in the CEC of soil cultivated with vines using green fertilization. One of the determining factors in this difference was the increased OM content in the cultivated soil, with a subsequent increase in exchange sites. According to Aprile and Lorandi et al. (2012), OM largely contributes to the CEC of soils, especially in the surface layer.

Discriminant and factor analyses were used to provide further explanation soil of the fertility changes in the vineyards. The combinations of correlated variables were clearly distinguished between cultivated and reference areas at both depths (Figure 2). There was no 

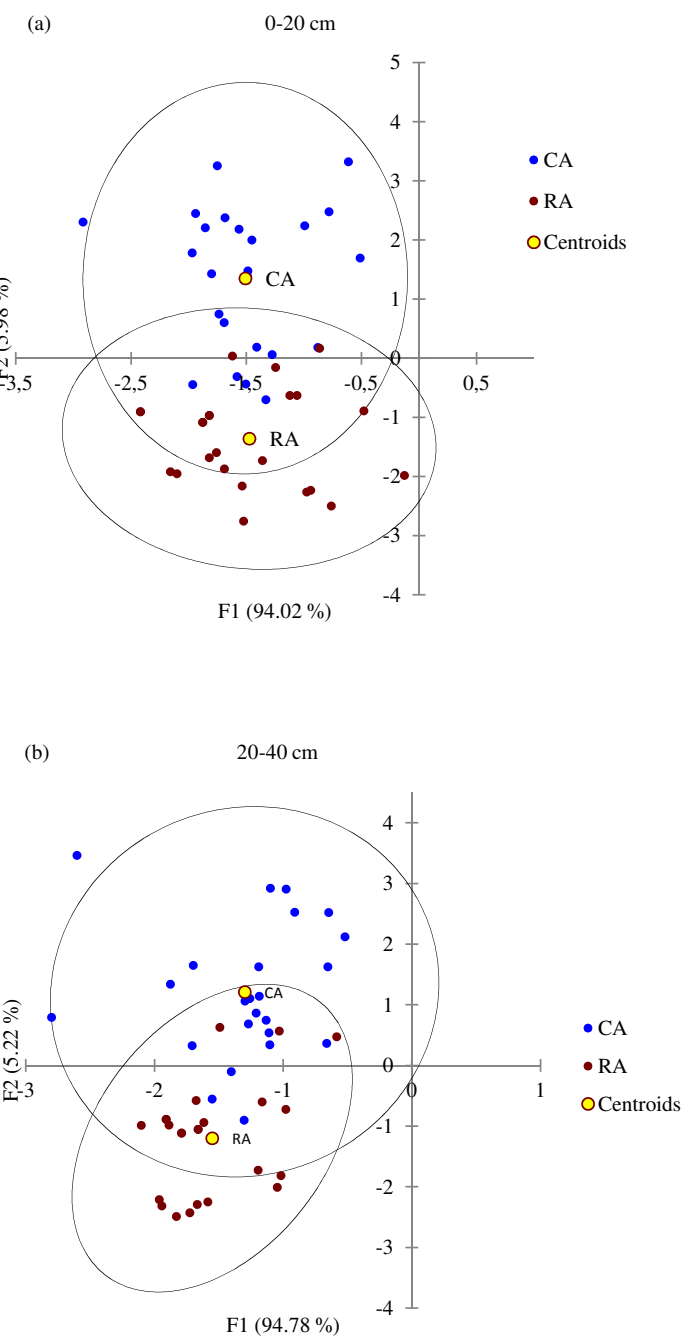

Figure 2. Discriminant analysis based on soil management. (a) 0-20 cm depth; (b) 20-40 cm depth.

significant difference among vineyard soils cultivated for $5,6,8,10,12,15$, and 16 years. More than $90 \%$ of samples from the reference areas were properly classified, whereas $83 \%$ of the samples in cultivated areas were adequately classified.
Phosphorus was the nutrient with the highest differences between the reference and cultivated areas, regardless of depth (Table 2). This reflects the great amounts of $\mathrm{P}$ applied to soils. These values probably exceed plant requirements, which Schmitt et al. (2013) also observed in vineyard soils. The very high 


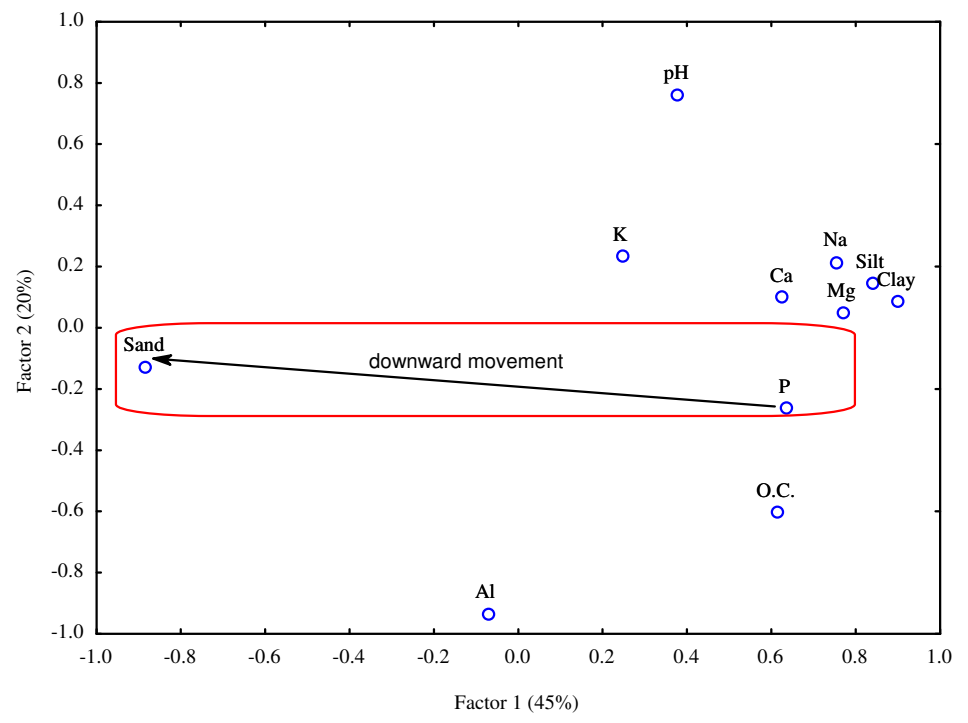

Figure 3. Factor analysis of chemical and physical data, according to Varimax raw rotation.

$\mathrm{P}$ concentrations found in the soils are a major concern in regard to eutrophication. We used the factor analysis technique to better address the downward movement of $\mathrm{P}$ (Figure 3).

Two factors with eigenvalues higher than unity explained roughly $65 \%$ of the total variance. Factor 1 was positively loaded on $\mathrm{P}(0.65), \mathrm{OC}(0.61), \mathrm{Ca}$ (0.62), $\mathrm{Mg}(0.76), \mathrm{Na}(0.75)$, silt (0.84), and clay $(0.90)$, while it was negatively loaded on sand (-0.88).

Factor 2 showed high positive and negative loadings on $\mathrm{pH}(0.77)$ and $\mathrm{Al}(-0.93)$. The opposite association between $\mathrm{P}$ and sand content confirms that $\mathrm{P}$ movement towards deep layers is mainly governed by soil texture (Silva et al., 2014). Therefore, the high and continuous application of $\mathrm{P}$ in these soils increases the potential of $\mathrm{P}$ leaching and contamination of surface and underground waters (Pizzeghello et al., 2011).
Other studies have shown that land use changes can modify P concentration and bioavailability (Redel et al., 2015). In contrast with other vineyard regions, in which metal contamination is the main environmental concern (Mackie et al., 2012; Navel and Martins, 2014), vineyard soils in São Francisco Valley are prone to $\mathrm{P}$ leaching and subsequent eutrophication. These sandy soils are more prone to leaching of nutrients (ions) and pesticides; this is due the low adsorption capacity of these soils. Therefore, these soils are (more easily than clay soils) a source of $\mathrm{P}$ and contaminants to other ecosystem compartments. Thus, best practices for management of $\mathrm{P}$ fertilization are essential to guarantee environmental sustainability (Balemi and Negisho, 2012). According to Junior et al. (2016), the input of crop residues plays an important role in reducing water and sediment losses. Schmitt et al. (2013) observed that long-cultivated vineyard soils 
under continued phosphate fertilization pose risk of contamination due to the high amount of $\mathrm{P}$ desorbed into surface and underground water. These studies showed that $\mathrm{P}$ equilibrium concentration can be properly used as an environmental indicator of $\mathrm{P}$ leaching.

\section{Conclusions}

In general, the transformation of Caatinga areas into cultivation fields increased $\mathrm{pH}$ and soil fertility. However, the management of the phosphate fertilization deserves attention since vineyards are among the most vulnerable sites affected by soil erosion processes, indicating a risk of surface water contamination. The intensive $\mathrm{P}$ application, especially via fertirrigation, built up the available $\mathrm{P}$ in soils to levels far beyond the amounts that grapes require. As a result of the low $\mathrm{P}$ adsorption capacity of the soils, high amounts of the element are prone to leach and can contribute to triggering eutrophication processes. Thus, best practices for the management of $\mathrm{P}$ fertilization are essential to guarantee high grape quality and environmental sustainability. The use of discriminant and factor analyses proved to be useful for distinguishing natural and cultivated areas, as well as aiding management practices that can preserve this fragile agroecosystem.

\section{References}

Aprile, F., Lorandi, R. 2012. Evaluation of cation exchange capacity (CEC) in tropical soils using four different analytical methods. Journal of Agricultural Science. 4, 278-289.

Almeida, J.A., Bertol, I., Leite, D., Amaral, A.J., Zoldan Júnior, W.A. 2005. Chemical properties of a Humic Cambisol under conventional tillage and no-tillage after six years of cropping. Brazilian Journal of Soil Science. 29, 437-445.
Araújo, M.A., Tormena, C.A., Watanabe, S.H., Pintro, J.C., Costa, A.C.S., Mata, J.D.V. 2000. Avaliação do impacto do cultivo nas características químicas e na agregação de um latossolo vermelho distrófico do noroeste do Paraná. Acta Scientiarum Agronomy. 22, 1045-1053.

Balemi, T., Negisho, K. 2012. Management of soil phosphorus and plant adaptation mechanisms to phosphorus stress for sustainable crop production: a review. Journal of Soil Science and Plant Nutrition. $12,547-561$.

BRASIL. 2014. Ministério da Agricultura. Culturas: uva. Disponível em: <http://www.agricultura.gov. br/vegetal/culturas/uva $>$ (accessed 18.03.2017).

Brunori, E., Farina, R., Biasi, R. 2016. Sustainable viticulture: The carbon-sink function of the vineyard agro-ecosystem. Agriculture, Ecosystems and Environment. 223, 10-21.

Cavalcante, E.G.S., Alves, M.C., Pereira, G.T., Souza, Z.M. 2007. Variabilidade espacial de MO, P, K e CTC do solo sob diferentes usos e manejos. Ciência Rural. 37, 394-400.

Duplay, J., Semhi, K., Errais, E., Imfeld, G., Babcsanyi, I., Perrone, T. 2014. Copper, zinc, lead and cadmium bioavailability and retention in vineyard soils (Rouffach, France): the impact of cultural practices. Geoderma. 230-231, 318-328.

Embrapa. 2011. Manual de métodos de análises de solo. $2^{\mathrm{a}}$ ed. Empresa Brasileira de Pesquisa Agropecuária (Embrapa), Rio de Janeiro, Brasil.

Faria, C.M.B., Silva, M.S.L., Silva, D.J. 2007. Alterações em características de solos do Submédio São Francisco sob diferentes sistemas de cultivo. Petrolina: Embrapa Semiárido. 33, 74 p.

Faria, C.M.B., Soares, J.M., Leão, P.C.S. 2004. Green manuring grapevine with legumes in the submiddle São Francisco River Valley. Brazilian Journal of Soil Science. 28, 641-648. 
Fernández-Calviño, D., Soler-Rovira, P., Polo, A., Díaz-Raviña, M., Arias-Estévez, M., Plaza, C. 2010. Enzyme activities in vineyard soils longterm treated with copper-based fungicides. Soil Biology and Biochemistry. 42, 2119-2127.

Fernández-Calviño, D., Arias-Estévez, M., DíazRaviña, M., Bååth, E., 2012. Assessing the effects of $\mathrm{Cu}$ and $\mathrm{pH}$ on microorganisms in highly acidic vineyard soils. European Journal of Soil Science. $63,571-578$.

Franchini, J.C., Meda, A.R., Cassiolato, M.E., Miyazawa, M., Pavan, M.A. 2001. Plant residue extracts potential for lime mobility in the soil using a biological method. Scientia Agricola. 58, $357-360$.

Freitas, N.O., Yano-Melo, A.M., Silva, F.S.B., Melo, N.F., Maia, L.C. 2011. Soil biochemistry and microbial activity in vineyards under conventional and organic management at Northeast Brazil. Scientia Agricola. 68, 223-229.

Gatiboni, L.C., Saggin, A., Brunetto, G., Horn, D., Flores, J.P.C., Rheinheimer, D.S., Kaminski, J. 2003. Alterações nos atributos químicos de solo arenoso pela calagem superficial no sistema plantio direto consolidado. Ciência Rural. 33, 283-290.

Gómez-Armesto, A., Carballeira-Díaz, J., Pérez-Rodríguez, P., Fernández-Calviño, D., Arias-Estévez, M., Nóvoa-Muñoz, J.C., Álvarez-Rodríguez, E., Fernández-Sanjurjo, M.J., Núñez-Delgado, A. 2015. Copper content and distribution in vineyard soils from Betanzos (A Coruña, Spain). Spanish Journal of Soil Science. 5, 60-71.

Junior, P.R.R., Bhattarai, R., Fernandes, R.B.A., Kalita, P.K., Andrade, F.V. 2016. Soil surface roughness under tillage practices and its consequences for water and sediment losses. Journal of Soil Science and Plant Nutrition. 16, 1065-1074.
Jiao, W., Chen, W., Chang, A.C., Albert, L. 2012. Environmental risks of trace elements associated with long-term phosphate fertilizers applications: a review. Environmental Pollution. 168, 44-53.

Lin, C., Lian, J., Fang, H., 2005. Soil lead immobilization using phosphate rock. Water, Air, \& Soil Pollution. 161, 113-123.

Mackie, K.A., Mueller, T., Kandeler, E. 2012. Remediation of copper in vineyards: a mini review. Environmental Pollution. 167, 16-26.

Navel, A., Martins, J.M.F. 2014. Effect of long term organic amendments and vegetation of vineyard soils on the microscale distribution and biogeochemistry of copper. Science of the Total Environment. 466-467, 681-689.

Pavinato, O.S., Rosolem, C.A. 2008. Effects of organic compounds produced by plants on soil nutrient availability. Brazilian Journal of Soil Science. 32, 911-920.

Pizzeghello, D., Berti, A., Nardi, S., Morari, F. 2011. Phosphorus forms and P-sorption properties in three alkaline soils after long-term mineral and manure applications in northeastern Italy. Agriculture, Ecosystems and Environment. 141, 58-66.

Preston, W., Silva, Y.J.A.B., Nascimento, C.W.A., Cunha, K.P.V., Silva, D.J., Ferreira, H.A. 2016. Soil contamination by heavy metals in vineyard of a semiarid region: An approach using multivariate analysis. Geoderma Regional. 7, 357-365.

Redel, Y.D., Escudey, M., Alvear, M., Conrad, J., Borie, F. 2015. Effects of land use change on P bioavailability determined by chemical fractionation and 31P-NMR spectroscopy in a Nothofagus forest and adjacent grassland. Journal of Soil Science and Plant Nutrition. 15, 1061-1070.

Santos, G.C.G., Valladares, G.S., Abreu, C.A., Camargo, O.A., Grego, C.R. 2013. Assessment 
of copper and zinc in soils of a vineyard region in the state of São Paulo, Brazil. Applied and Environmental Soil Science. http://dx.doi. org/10.1155/2013/790795.

Schmitt, D.E., Comin, J.J., Ceretta, C.A., Gatiboni, L.C., Tiecher, T., Lorensini, F., Heinzen, J., Ambrosini, V.G., Moraes, M.P., Brunetto, G. 2013. Accumulation of phosphorus fractions and contamination potential in vineyard soils in the southern region of the state of Santa Catarina, Brazil. Brazilian Journal of Soil Science. 37, 1256-1266.

Serrano, J., Silva, J.M., Shahidian, S., Silva, L.L., Sousa, A., Baptista, F. 2017. Differential vineyard fertilizer management based on nutrients spatiotemporal variability. Journal of Soil Science and Plant Nutrition, ahead of print. http://dx.doi. org/10.4067/S0718-95162017005000004.

Silva, J.P.S., Nascimento, C.W.A., Silva, D.J., Cunha, K.P.V., Biondi, C.M. 2014. Changes in soil fer- tility and mineral nutrition of mango orchards in São Francisco Valley, Brazil. Revista Brasileira de Ciências Agrárias. 9, 42-48.

Teixeira, A.H.C. 2010. Informações agrometeorológicas do Polo Petrolina, PE/Juazeiro, BA - 1963 a 2009. Petrolina: Embrapa Semiárido, 21p.

Tiecher, T., Oliveira, L.B., Caner, L., Brunetto, G., Bortoluzzi, E.C., Santos, D.R., Casali, C.A., Zafar, M., Tiecher, T.L. 2015. Cover crops affecting soil phosphorus dynamics in Brazilian highly weathered soils, $23 \mathrm{p}$.

Wightwick, A.M., Salzman, S.A., Reichman, S.M., Allinson, G., Menzies, N.W. 2013. Effects of copper fungicide residues on the microbial function of vineyard soils. Environmental Science and Pollution Research. 20, 1574-1585. 